\title{
MAKALAH \\ MANAJEMEN PROYEK SISTEM INFORMASI
}

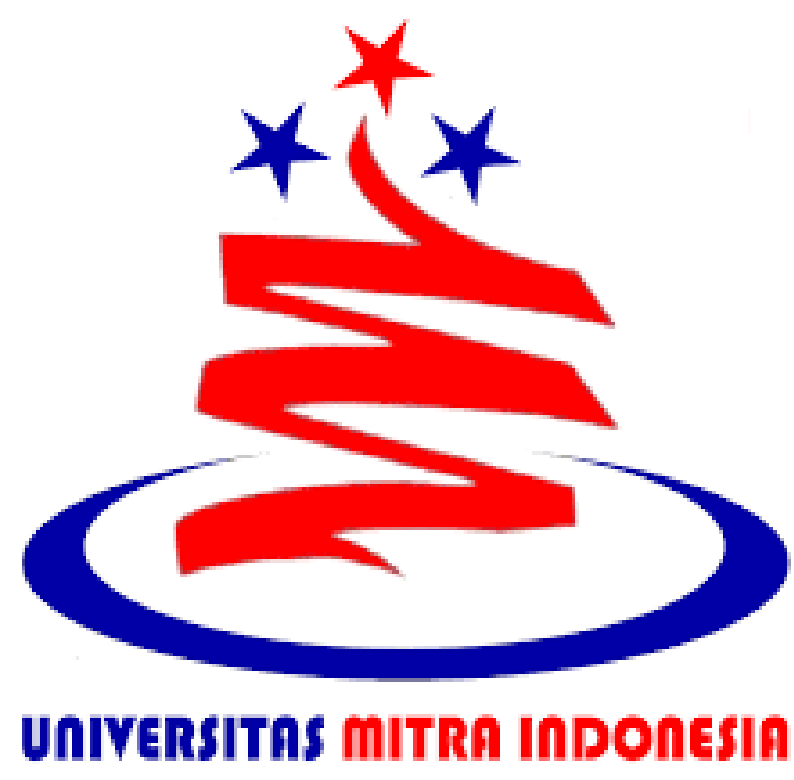

Disusun oleh:

Nadya Karina Putri

NPM 175100066

Universitas Mitra Indonesia

2019 


\section{BAB I}

\section{PENDAHULUAN}

Manajemen proyek itu suatu disiplin ilmu pada era tahun 1950-an, Amerika bangsa yang pertama kali menggunakan ilmu manajemen proyek. Henry Gantt dapat dikatakan bapak dari ilmu manajemen proyek, dan namanya pun menjadi metode yang digunakan, bernama "Gantt Chart". Perlu diingat bahwa mempelajari Manajemen Proyek itu tidak terlalu sulit, karena didalamnya terdapat hal-hal yang terbiasa dilakukan oleh manusia, hanya ditambahkan sedikit logika dan aturan yang khusus. Sedangkan Proyek itu usaha yang harus dilakukan dari awal hingga akhir pada suatu kejadian, yang mempunyai batasan waktu - anggaran - sumber daya yang dibutuhi oleh pelanggan. Meski pada akhir tujuan dari adanya proyek adalah untuk memuaskan pelanggan.

\subsection{Latar Belakang}

Sebagai mahasiswa sistem informasi kita dituntut untuk memahami bagaimana manajemen proyek sistem informasi itu agar ilmu ini bisa di implementasikan dalam kehidupan nyata.

Untuk mengetahui secara lebih jelas tentang manajemen proyek sistem informasi maka selanjutnya akan dibahas lebih mendetail mulai dari pengertian hingga metodologi umum pelaksanaan proyek sistem informasi.

\subsection{Rumusan Masalah}

a. Pengertian manajemen, proyek dan manajemen proyek.

b. Kebijakan dan Perencanaan Proyek Sistem Informasi.

c. Metodologi Umum Pelaksanaan Proyek Sistem Informasi.

\subsection{Tujuan dan Manfaat}

a. Untuk mengetahui dan memahami pengertian-pengertian manajemen, proyek dan manajemen proyek.

b. Mengetahui kebijakan dan perencanaan proyek sistem informasi.

c. Mengetahui Metodologi Umum Pelaksanaan Proyek Sistem Informasi. 


\section{BAB II}

\section{PEMBAHASAN}

\subsection{Pengertian Manajemen}

Manajemen merupakan sebuah proses terpadu dimana individu-individu sebagai bagian dari organisasi yang dilibatkan untuk merencanakan, mengorganisasikan, menjalankan dan mengendalikan aktifitas-aktifitas, yang kesemuanya diarahkan pada sasaran yang telah ditetapkan dan berlangsung terus menerus seiring dengan berjalannya waktu. Agar proses manajemen berjalan lancar, diperlukan sistem serta struktur organisasi yang solid. Pada organisasi tersebut, seluruh aktifitasnya haruslah berorientasi pada pencapaian sasaran. Organisasi tersebut berfungsi sebagai wadah untuk menuangkan konsep, ide-ide manajemen. Jadi dapat dikatakan bahwa manajemen merupakan suatu rangkaian tanggung jawab yang berhubungan erat satu sama lainnya.

Skill yang dibutuhkan ada 4 titik, yaitu kepada Owner, User, Lingkungan, dan Team. Maksudnya, Ketika seorang proyek manager berurusan dengan owner (komisaris perusahaan) dapat memberikan informasi berupa biaya/budget dari segi finansial, seta resiko kedepan yang akan dihadapi. Ketika berbicara dengan user, dapat mengajak untuk menggunakan hasil dari proyek, baik meloby dan bujuk rayu.

Manajer proyek adalah seseorang yang memiliki tanggung jawab terbesar atas pelaksanaan proyek. Pekerjaan utama dari manajer proyek adalah mengarahkan, mengawasi dan mengendalikan proyek dari awal sampai selesai. Hal-hal yang perlu dilakukan seorang manajer proyek adalah :

a. Manajer proyek harus mendefinisikan proyek, membreakdown proyek menjadi serangkaian tugas(tasks) yang mudah dikelola, memperoleh sumberdaya yang dibutuhkan, dan membentuk tim kerja untuk melaksanakan tugas-tugas tersebut.

b. Manajer proyek harus menetapkan tujuan akhir dari proyek dan memitivasi anggota tim kerja untuk menyelesaikan proyek tepat waktu

c. Manajer proyek harus menginformasikan kepada stakeholder tentang perkembangan pelaksanaan proyek secara periodik.

d. Manajer proyek harus mengenali resiko yang mungkin terjadi dan meminimalkan dampak terhadap penyelesaian proyek.

e. Manajer proyek harus beradaptasi terhadap perubahan-perubahan, karena tidak ada proyek yang $100 \%$ berjalan sesuai dengan yang direncanakan. Berkaitan dengan tugas-tugas seorang manajer, maka area kemampuan yang perlu dimiliki oleh seorang manajer adalah: kepemimpinan, manajemen orang (konsumen, suplier, manajer dan kolega), komunikasi , negosiasi, perencanaan, manajemen kontrak, pemecahan masalah dan berpikir kreatif). Banyak kesalahan terjadi dalam mengelola sebuah proyek yang menyebabkan sering menjadi hambatan. Hambatan-hambatan yang mungkin terjadi adalah: 
- komunikasi yang tidak baik (Poor communication)

- persetujuan yang tidak jelas (Disagreement)

- kesalahpahaman (Misunderstandings).

- suasana yang tidak mendukung (Bad weather)

- pemogokan kerja (Union strikes)

- konflik pribadi (Personality conflicts)

- manajemen yang tidak baik (Poor management)

- definisi sasaran dan tujuan tidak jelas (Poorly defined goals and objectives)

Manajer proyek yang baik tidak menghindari semua resiko, tetapi menyiapkan proses dan prosedur standart untuk berusaha mencegah resiko yang mungkin terjadi seperti:

1. Keterlambatan penyelesaian proyek, pembekakkan anggaran atau keingingan konsumen tidak terpenuhi.

2. Tidak konsisten antara proses dan prosedur yang digunakan manajer proyek

3. Proyek tidak bermanfaat dan membuang-buang waktu dan biaya

4. Tidak sinerginya faktor internal dan eksternal yang mempengaruhi proyek.

\subsubsection{Pengertian Proyek}

Proyek merupakan suatu tugas yang perlu dirumuskan untuk mencapai sasaran yang dinyatakan secara kongkrit serta harus diselesaikan dalam suatu periode tertentu dengan menggunakan tenaga manusia dan alat-alat yang terbatas dan begitu kompleks sehingga dibutuhkan pengelolaan dan kerjasama yang berbeda dari yang biasanya digunakan.

Menurut DI Cleland dan Wr. King (1987), proyek merupakan gabungan dari berbagai sumber daya yang dihimpun dalam organisasi sementara untuk mencapai suatu tujuan tertentu.

Timbulnya suatu proyek antara lain dilatar belakangi oleh:

1. Rencana pemerintah. misalnya proyek pembangunan jalan

2. Permintaan pasar. misalnya terjadi kenaikan permintaan suatu produk dalam jumlah besar, maka perlu dibangun sarana produksi baru.

3. Dari dalam perusahaan yang bersangkutan. misalnya suatu perusahaan akan memperbarui (modernisasi) perangkat, sistem kerja, atau sistem informasi yang lama agar lebih mampu bersaing.

4. Dari kegiatan penelitian dan pengembangan. dari kegiatan penelitian dan pengembangan diperkirakan dapat dihasilkan produk baru yang banyak manfaat dan peminatnya, sehingga dibangun fasilitas produksinya.

Macam-Macam Proyek :

Menurut R.D Achibalt (1976), macam-macam proyek adalah sebagai berikut :

1. Proyek Kapital (Modal). Meliputi : pembebasan tanah, pembelian material dan peralatan, desain mesin, dan kostruksi guna pembangunan instalasi pabrik baru. 
2. Proyek pengembangan produk baru adalah kegiatan untuk menciptakan produk baru yang biasanya merupakan gabungan antara proyek kapital dan proyek riset dan pengembangan. Contoh : penemuan alat elektronik karaoke.

3. Proyek penelitian dan pengembangan berupa kegiatan untuk melakukan penelitian dengan sasaran yang ditentukan.

4. Proyek sistem informasi adalah kegiatan yang sifatnya spesifik dengan mempergunakan alat-alat pemrosesan data (data processing personal dan alat-alat lainnya).

5. Proyek yang berkaitan dengan manajemen : perusahaan merancang reorganisasi, perusahaan merancang program efisiensi, dan penghematan merancang diversifikasi.

\subsubsection{Manajemen Proyek}

Manajemen proyek merupakan suatu usaha merencanakan, mengorganisasi, mengarahkan, mengkoordinasi, dan mengawasi kegiatan dalam proyek sedemikian rupa sehingga sesuai dengan jadwal waktu dan anggaran yang telah ditetapkan. Suatu pekerjaan rutin biasanya berlangsung secara kontinu, berulang-ulang dan berorientasi ke proses. Sebagai suatu proses yang terus menerus, pekerjaan yang rutin tidak dianggap suatu proyek.

Pengelola dalam sebuah proyek disebut sebagai Proyek Manager (PM), Proyek Manager bertanggung jawab untuk mengatur dan mengawasi semua kegiatan pelaksanaan proyek, agar sesuai dengan standart kualitas, biaya dan waktu. Dan tentunya selalu bertanggung jawab untuk selalu berkomunikasi dengan tim, atasan (owner), dan pelanggan (user).

Manfaat manajemen proyek:

- Mengidentifikasi fungsi tanggung jawab

- Meminimalkan tuntutan pelaporan rutin

- Mengidentifikasi batas waktu untuk penjadwalan

- Mengidentifikasi metode analisa peramalan

- Mengukur prestasi terhadap rencana

- Mengidentifikasi masalah dini \& tindakan perbaikan

- Meningkatkan kemampuan estimasi untuk rencana

- Mengetahui jika sasaran tidak dapat dicapai/terlampaui

Konsep Manajemen Proyek :

Manajemen proyek sistem informasi ditekankan pada tiga faktor, yaitu : manusia, masalah dan proses. Dalam pekerjaan sistem informasi faktor manusia sangat berperan penting dalam suksesnya manajemen proyek. Pentingnya faktor manusia dinyatakan dalam model kematangan kemampuan manajement manusia (a people management capability maturity model/ PM-CMM) yang berfungsi untuk meningkatkan kesiapan organisasi perangkat lunak (sistem informasi) dalam menyelesaikan masalah dengan melakukan kegiatan menerima, memilih, kinerja manajemen, pelatihan, kompensasi, pengembangan karier, organisasi dan rancangan kerja serta pengembangan tim. 


\section{Dasar-Dasar Organisasional :}

Organisasi adalah sistem yang saling mempengaruhi dan saling bekerja sama antara orang yang satu dengan orang yang lain dalam suatu kelompok untuk mencapai suatu tujuan tertentu yang telah disepakati bersama. Organisasi merupakan sistem maka terdiri dari beberapa elemen yaitu :

a) orang, dalam organisasi harus ada sekelompok orang yang bekerja dan salah satunya ada yang memimpin organisasi tersebut.

b) tujuan, dalam organisasi harus ada tujuan yang harus dicapai, baik dalam jangka pendek maupun jangka panjang.

c) posisi, setiap orang yang ada dalam suatu organisasi akan menempati posisi atau kedudukannya masing-masing.

d) pekerjaan, setiap orang yang ada dalam organisasi tersebut mempunyai pekerjaan (job) masing-masing sesuai dengan posisinya.

e) teknologi, untuk mencapai tujuan organisasi membutuhkan teknologi untuk membantu dalam pengolahan data menjadi suatu informasi.

f) struktur, struktur organisasi merupakan pola yang mengatur pelaksanaan pekerjaan dan hubungan kerja sama antar setiap orang yang ada dalam organisasi tersebut.

g) lingkungan luar, merupakan elemen yang sangat penting dan akan mempengaruhi keberhasilan suatu organisasi, misalnya adanya kebijakan pemerintah tentang organisasi.

Prinsip-prinsip organisasi adalah nilai-nilai yang digunakan sebagai landasan kerja bagi setiap orang yang ada dalam organisasi tersebut untuk mencapai keberhasilan tujuan yang telah disepakati. Prinsip-prinsip yang ada dalam organisasi meliputi :

- Tujuan organisasi yang jelas

- Tugas yang dilakukan harus jelas

- Pembagian tugas yang adil

- Penempatan posisi yang tepat

- Adanya koordinasi dan integrasi

\subsection{Kebijakan dan Perencanaan Proyek Sistem Informasi}

Sistem Informasi memiliki pengertian suatu sistem yang memiliki fungsi menghasilkan informasi-informasi yang dibutuhkan pihak user. Komponen yang termasuk sistem informasi meliputi infrastruktur hardware, Software dan ketersediaan sumber daya manusia bidang teknologi informasi. Proyek sistem informasi mencakup sebagian atau keseluruhan dari rangkaian aktivitas rekayasa pembangunan sistem informasi. Contoh-contoh proyek sistem informasi

- Proyek sistem informasi untuk mendukung pelaksanaan pemilu 
- Proyek pembangunan infrastruktur E-Government di Jawa Tengah

- Proyek penjualan elektronik (E-Commerce)

Beberapa perbedaan karakteristik proyek sistem informasi dibandingkan dengan proyek bidang lain adalah sebagai berikut :

1. Memiliki tujuan untuk menghasilkan produk yang bersifat intangible (tidak dapat diraba/perkirakan, tidak dapat dinyatakan secara jelas) seperti perangkat lunak, database, jaringan yang sulit untuk mengukur nilai manfaat dari produk tersebut.

2. Melibatkan teknologi yang sangat cepat usang, karena perkembangan yang sangat cepat.

3. Membutuhkan beragam sumber daya manusia dengan keahlian dan kompetensi yang beragam

4. Ukuran yang dijadikan standar sulit dibakukan, karena sulit mengukur kualitas yang dimengerti berbagai pihak secara seragam.

\section{Kebijakan Sistem}

Kebijakan untuk mengembangkan sistem informasi dilakukan oleh manajemen puncak karena manajemen menginginkan untuk meraih kesempatan-kesempatan yang ada yang tidak dapat diraih oleh sistem yang lama atau sistem lama mempunyai kelemahan (masalah) perencanaan sistem menyangkut estimasi (penafsiran, perkiraan, pendapat atau penilaian) sumberdaya (kebutuhan-kebutuhan fisik dan tenaga kerja) dan biaya.

Proses perencanaan sistem dapat dikelompokkan dalam tiga proses utama, yaitu :

1. Merencanakan proyek-proyek sistem

Tahapan proses perencanaan sistem yaitu :

- Mengkaji tujuan, perencanaan strategi dan taktik perusahaan.

- Mengidentifikasi proyek-proyek sistem.

- Menetapkan sasaran proyek-proyek sistem.

- Menetapkan kendala proyek-proyek sistem.

- Menetukan prioritas proyek-proyek sistem.

- Membuat laporan perencanaan sistem.

- Meminta persetujuan manajemen.

2. Mempersiapkan proyek-proyek sistem yang akan dikembangkan meliputi :

1. Menunjuk team analis (dapat berasal dari departemen pengembangan yang ada atau dari luar perusahaan (konsultan).

2. Mengumumkan proyek pengembangan system.

3. Mendefinisikan proyek-proyek sistem yang dikembangkan

Melakukan studi untuk mencari alternatif pemecahan terbaik yang paling layak untuk dikembangkan. 
Tahapan yang dilakukan yaitu :

- Mengidentifikasi kembali ruang lingkup dan sasaran proyek system.

- Melakukan studi kelayakan.

- Menilai kelayakan proyek system.

- Membuat usulan proyek system.

- Meminta persetujuan manajemen.

Perkiraan Proyek Sistem Informasi

Sekarang biaya merupakan elemen yang paling penting dan mahal dalam pengembangan sistem berbasis komputer. Perkiraan biaya yang salah atau kurang tepat dapat mengurangi keuntungan atau malah kerugian. Perkiraan biaya sistem informasi dan usaha tidak dapat dihitung dengan tepat, karena banyak variabel (manusia, teknikal, lingkungan) yang mempengaruhinya. Untuk mencapai perkiraan biaya dan usah yang dapat diandalkan, digunakan pilihan sebagai berikut :

- Memperkirakan waktu yang paling lama dari pengerjaan proyek.

- Perkiraan berdasarkan pada proyek yang sama.

- Menggunakan teknik dekomposis.

- Menggunakan satu atau lebih model empiris.

Memperkirakan waktu untuk menyelesaikan setiap kegiatan merupakan bagian yang paling sulit, untuk itu butuh pengalaman dalam memperkirakan waktu yang diperlukan. Penjadwalan tugas-tugas (kegiatan) dapat menggunakan :

\section{Grafik Gantt}

Merupakan suatu grafik dimana ditampilkan kotak-kotak yang mewakili setiap tugas (kegiatan) dan panjang masing-masing setiap kotak menunjukkan panjang relatif tugas-tugas yang dikerjakan.

\section{Diagram PERT (Program Evaluation and Review Techniques)}

Suatu program (proyek) diwakili dengan jaringan simpul dan tanda panah yang kemudian dievaluasi untuk menentukan kegiatan-kegiatan terpenting, meningkatkan jadwal yang diperlukan dan merevisi kemajuan-kemajuan saat proyek telah dijalankan.

Diagram PERT lebih baik dari Gantt, karena :

- Mudah mengidentifikasi tingkat prioritas.

- Mudah mengidentifikasi jalur kritis dan kegiatan-kegiatan kritis.

- Mudah menentukan waktu kendur.

- Penjadwalan proyek berbasis komputer.

Menggunakan PC untuk membuat jadwal proyek lebih praktis dan menguntungkan. Contoh program penjadwalan yaitu Ms Project, Symantec's Timeline dan Computer Associates' CA- 
Super Project. Proses pengembangan sistem informasi dikembangkan oleh pelaku-pelaku yang dapat dikatagorikan dalam 5 kelompok :

1. Manajer senior, yang bertugas mendefinisikan permasalahan-permasalahan bisnis dan sangat berpengaruh pada proyek tersebut.

2. Manajer proyek (teknik), yang merencanakan, memotivasi, mengorganisasi dan mengontrol orang-orang yang bekerja dalam proyek tersebut (praktisi).

3. Praktisi, adalah orang yang mempunyai kemampuan teknis yang dibutuhkan untuk mendapatkan produk sistem informasi (program aplikasi).

4. Pelanggan, adalah orang yang membutuhkan sistem informasi (PL) tersebut.

5. Pengguna akhir, orang yang berinteraksi dengan sistem informasi (PL) yang dikaitkan dengan penggunaan produk.

Sedangkan contoh Manajemen Proyek antara lain:

- Proyek Pembuatan Website

- Proyek Pembuatan Software

- Proyek Pembuatan Aplikasi

- Proyek pembuatan Robot

\subsection{Tahap Perencanaan}

Tahap perencanaan merupakan suatu rangkaian kegiatan semenjak ide pertama yang melatarbelakangi pelaksanaan proyek ini didapat, pendefinisian awal terhadap kebutuhan detail atau target yang harus dicapai dari proyek tersebut, penyusunan proposal, penentuan metodologi dan sistem manajemen proyek yang digunakan, sampai dengan penunjukan tim dan instruksi untuk mengeksekusi (memulai) proyek yang bersangkutan. Biasanya ada dua pihak yang terlibat langsung dalam proyek perencanaan ini yaitu :

a) Pihak yang membutuhkan (demand side) eksistensi dari suatu sistem informasi, dalam hal ini adalah perusahaan, lembaga, institusi atau organisasi yang bersangkutan.

b) Pihak yang berusaha menjawab kebutuhan tersebut (supply side) dalam bentuk pengembangan teknologi informasi. Kelompok ini biasanya merupakan gabungan dari para personel yang terkait dengan latar belakang ilmu dan pengetahuan yang beragam (multidisiplin), seperti ahli perangkat lunak, analisis bisnis dan manajemen, spesialis perangkat keras, programmer, sistem analis, praktisi hukum, manajer proyek dan beberapa karakteristik SDM lain yang terkait.

\subsection{Tahap Analisis}

Secara prinsip ada 2 aspek yang jadi fokus analisis, yaitu :

1. Aspek bisnis atau manajemen

Analisis aspek bisnis dimulai dengan mempelajari karakteristik perusahaan yang bersangkutan, mulai dari aspek-aspek historis, struktur kepemilikan, visi, misi, kunci 
keberhasilan usaha (critical success factors), ukuran kinerja (performance measurements), strategi, program-program dan hal terkait lainnya.

Tujuan dilakukannya langkah ini :

a) Mengetahui posisi atau peranan teknologi informasi yang paling sesuai dan relevan di perusahaan (mengingat setiap perusahaan memiliki pandangan tersendiri dan unik terhadap sumber daya teknologi yang dimiliki, yang membedakannya dengan perusahaan lain).

b) Mempelajari fungsi-fungsi manajemen dan aspek-aspek bisnis terkait yang akan berpengaruh (memiliki damppak tertentu) terhadap proses desain, konstruksi dan implementasi.

\section{Aspek teknologi}

Analisis aspek teknologi meliputi kegiatan-kegiatan yang bersifat menginventarisir aset teknologi informasi yang dimiliki perusahaan pada saat proyek dimulai dengan berbagai tujuan, antara lain :

a) Mempelajari infrastruktur teknologi informasi yang dimiliki perusahaan dan tingkat efektivitas penggunaannya selama kurun waktu tersebut.

b) Menganalisis kemungkinan-kemungkinan diperlukannya penambahan sistem di kemudian hari (system upgrading) sehubungan akan diimplementasikannya teknologi baru.

Keluaran dari proses analisis di kedua aspek ini adalah isu-isu (permasalahan) penting yang harus segera ditangani, dianalisis penyebabnya, dampaknya bagi bisnis perusahaan, beberapa kemungkinan scenario pemecahan dengan segala resiko cost/benefit (laba/rugi) dantradeoff (tukar tambah), serta pilihan solusi yang direkomendasikan. Sebelum memasuki fase desain, seluruh tim harus paham tentang isu-isu ini dan memiliki komitmen untuk melanjutkan proyek yang ada ke tahap berikutnya sesuai dengan skala prioritas yang telah ditentukan (setelah memilih scenario yang disetujui bersama).

\subsection{Tahap Desain}

Pada tahap desain, tim teknologi informasi bekerja sama dengan tim bisnis atau manajemen melakukan perancangan komponen-komponen sistem terkait. Tim teknologi informasi akan melakukan perancangan teknis dari teknologi informasi yang akan dibangun, seperti sistem basis data, jaringan computer, metode interfacing, teknik konversi data, metode migrasi sitem dan sebagainya.

Model-model umum seperti Flowchart, ER Diagram, DFD dan lain sebagainya dipergunakan sebagai notasi umum dalam perancangan sistem secara teknis. Sementara itu secara paralel dan bersama-sama tim bisnis atau manajemen akan melakukan perancangan terhadap komponen-komponen organisasi yang terkait seperti prosedur (SOP = Standar Operation Procedures), struktur organisasi, kebijakan-kebijakan, teknik pelatihan, pendekatan SDM dan sebagainya. Tim ini pun biasanya akan mempergunakan model-model umum seperti Porter's 
Value Chain, Bussiness Process Mapping, Strategic Distinction Model, BCG Matrix, dan lain-lain.

\subsection{Tahap Konstruksi}

Berdasarkan desain yang telah dibuat, konstruksi atau pengembangan sistem yang sesungguhnya (secara fisik) dibangun. Tim teknis merupakan tulang punggung pelaksana tahap ini, mengingat semua hal yang bersifat konseptual harus diwujudkan dalam suatu konstruksi teknologi informasi dalam skala detail.

Dari semua tahapan yang ada, tahap konstruksi inilah yang biasanya paling banyak melibatkan sumber daya terbesar, terutama dalam hal SDM, biaya, waktu. Control terhadap manajemen proyek pada tahap konstruksi harus diperketat agar tidak terjadi ketidakefisienan maupun ketidakefektifan dalam penggunaan beragam sumber daya yang ada (yang secara tidak langsung akan berdampak langsung terhadap keberhailan proyek sistem informasi yang diselesaikan secara tepat waktu). Akhir dari tahap konstruksi biasanya berupa uji coba sistem. Perbaikan-perbaikan bersifat minor biasanya harus dilakukan setelah adanya masukanmasukan yang timbul setelah diadakannya evaluasi.

\subsection{Tahap Implementasi}

Tahap Implementasi merupakan tahap yang paling kritis karena untuk pertama kalinya sistem informasi akan dipergunakan di dalam perusahaan. Biasanya, pendekatan yang dipergunakan oleh perusahaan adalah pendekatan cut off dan paralel.

a) Pendekatan cut off atau big-bang adalah suatu strategi implementasi yang memilih sebuah hari sebagai patokan dan terhitung mulai hari tersebut, sistem baru mulai dipergunakan dan sistem lama ditinggalkan sama sekali.

b) Pendekatan paralel dilakukan dengan cara melakukan pengenalan sistem baru sementara sistem lama belum ditinggalkan, sehingga dua buah sistem berjalan secara paralel (kedua sistem tersebut biasa disebut testing environment dan production environment).

Pemilihan terhadap kedua strategi tersebut tergantung pada perusahaan masing-masing, karena masing-masing strategi implementasi memiliki keuntungan dan kerugian yang berbeda. Lepas dari strategi yang dipilih, pemberian pelatihan (training) harus diberikan kepada semua pihak yang terlibat sebelum tahap implementasi dimulai. Selain untuk mengurangi resiko kegagalan, pemberian pelatihan juga berguna untuk menanamkan rasa memiliki (sense of ownership) terhadap sistem baru yang diterapkan.

\subsection{Tahap Pascaimplementasi}

Dari segi teknis, yang dimaksud dengan aktivitas-aktivitas pasca implementasi adalah bagaimana manajemen pemeliharaan sistem akan dikelola (maintenance, supports and services management). Seperti halnya sumber daya yang lain, sistem informasi akan mengalami perkembangan dikemudian hari. Hal-hal seperti modifikasi sistem, interfacing ke sistem lain, perubahan hak akses sistem, penanganan terhadap fasilitas pada sistem yang 
rusak, merupakan beberapa contoh dari kasus-kasus yang biasa timbul dalam pemeliharaan sistem. Di sinilah perlunya dokumentasi yang baik dan transfer of knowledge dari pihak pembuat sistem ke SDM perusahaan untuk menjamin terkelolanya proses-proses pemeliharaan sistem..

Dari segi manajemen, tahap pascaimplementasi adalah berupa suatu aktivitas, harus ada personel atau divisi dalam perusahaan yang dapat melakukan perubahan atau modifikasi terhadap sistem informasi sejalan dengan perubahan kebutuhan bisnis yang teramat dinamis.. Sistem informasi atau teknologi informasi yang secara teknis tidak dapat beradaptasi terhadap perubahan kebutuhan bisnis perusahaan sudah selayaknya tidak mendapatkan tempat yang baik.

\section{Studi kasus Proyek Pembuatan Software}

Proses pembuatan software tidak cukup hanya dikerjakan dalam waktu beberapa hari saja. Ada beberapa tahapan yang harus dilalui dalam proses pembuatan software. Setiap tahapan bisa memerlukan waktu cukup lama, bisa satu bulan, dua bulan, atau bahkan satu tahun. Tahapan-tahapan itu yaitu : requirement (perencanaan dan analisa), design (pembuatan), dan testing (pengujian dan pemeliharaan). Setiap tahapan yang dilalui terdapat beberapa permasalahan-permasalahan yang timbul.

Pada permasalahan ini akan dibahas beberapa permasalahan yang timbul dengan studi kasus pembuatan software Sistem Informasi Akademik dan juga akan dibahas solusi yang dapat diambil untuk mengatasi beberapa permasalahan tersebut. Pembahasan permasalahan ini dibagi dalam setiap tahapan pembuatan software.

\section{a) Tahap Requirement}

Pada tahap ini, kegiatan yamg paling banyak dilakukan adalah dengan melakukan interaksi dengan user. Permasalahan dalam proses pembuatan software yang dapat timbul pada tahap ini adalah :

1. Permasalahan spesifikasi kebutuhan

Kebutuhan akan fitur dan report yang diinginkan sering kali tidak sesuai dengan sistem yang ada. Misalnya pada sistem Informasi Akademik, user menginginkan report pembayaran SPP, sedangkan sistem ini hanya mengenai masalah akademik perkuliahan.

2. Ketidak sepahaman sistem antara developer dan user

Seringkali antara developer dan user dikarenakan perbedaan pemahaman, terjadi ketidak sepahaman mengenai alur Sistem Informasi Akademik, misalnya alur mulai dari mahasiswa bayar SPP, daftar ulang, pengisian FRS, proses perkuliahan sampai nilai akhir UAS keluar.

3. Metode analisa sistem 
Metode analisa sistem yang digunakan oleh developer tidak sesuai dengan kondisi/ behaviour user.

\section{b) Tahap Design}

Pada tahap ini, merupakan tahap yang dilakukan oleh developer. Permasalahan dalam proses pembuatan software yang dapat timbul pada tahap ini adalah :

1. Metode pembuatan software

Metode dan tools yang digunakan hasilnya tidak optimal, sesuai dengan keinginan user.

2. Organisasi pembuatan software

Tidak adanya koordinasi pada saat proses pembuatan software, sehingga terjadi modul-modul yang tidak dapat digabungkan. Misalnya tidak sesuainya nama tabel, field, atau tipe data yang digunakan.

\section{c) Tahap Testing}

Pada tahap ini, merupakan tahap pengujian software yang dilakukan antara developer dan user, dan diakhiri dengan pemeliharaan software. Permasalahan dalam proses pembuatan software yang dapat timbul pada tahap ini adalah :

1. Perubahan regulasi sistem

Adanya perubahan regulasi sistem, misalnya perubahan evaluasi penilaian dari 5 tingkat penilaian (A, B, C, D, E) menjadi 7 tingkat penilaian (A, AB, B, BC, C, D, E). Hal ini menyebabkan perubahan tabel dan fieldnya.

2. Ketidaksesuaian keinginan user dengan software yang telah dibuat

Pengujian software yang dilakukan antara user dan developer tidak memenuhi keinginan user.

3. Tidak adanya Risk Management

Hal ini menyebabkan tidak ada langkah-langkah yang akan dilakukan apabila terjadi revisi ataupun pada masa garansi/ maintenance.

Untuk mengatasi beberapa permasalahan tersebut diatas, perlu dilakukan analisa untuk mendapat solusinya. Ada beberapa solusi yang dapat diambil, antara lain :

- Membuat dokumen kontrak antara developer dan user sebelum proses pembuatan software.

- Perlu adanya assessment pada saat survey data, wawancara, ataupun analisa data. Assessment ini ditandangani kedua belah pihak, user dan developer.

- Menggunakan requirement tool untuk proses requirement sehingga dapat dihasilkan requirement yang sesuai dengan kebutuhan user. 
- Menentukan Proces Model yang akan digunakan pada awal proses pembuatan software, dapat menggunakan waterfall model, RAD model, spiral model, atau model lainnya.

- Membuat project management pada proses pembuatan software dengan dikoordinasi seorang penanggung jawab.

- Menentukan software programming untuk semua modul yang akan dibuat, termasuk tabel, relasi, dan struktur data.

- Membuat dokumen Berita Acara Pengujian Software sehingga dapat dinilai tingkat kepuasaan user terhadap software yang telah dibuat.

- Developer melakukan evaluasi total setiap selesai pembuatan software sebelum pengujian. 


\section{BAB III}

\section{PENUTUP}

Kesimpulan

1. Manajemen merupakan sebuah proses terpadu dimana individu-individu sebagai bagian dari organisasi yang dilibatkan untuk merencanakan, mengorganisasikan, menjalankan dan mengendalikan aktifitas-aktifitas, yang kesemuanya diarahkan pada sasaran yang telah ditetapkan dan berlangsung terus menerus seiring dengan berjalannya waktu.

2. Menurut DI Cleland dan Wr. King (1987), proyek merupakan gabungan dari berbagai sumber daya yang dihimpun dalam organisasi sementara untuk mencapai suatu tujuan tertentu.

3. Manajemen proyek adalah suatu cara mengelola, mengarahkan, dan mengkoordinasikan sumber daya (manusia/material)disaat mulainya sebuah proyek hingga akhir untuk mencapai suatu tujuan, yang dibatasi oleh biaya, waktu, dan kualitas untuk mencapai kepuasan.

4. Suatu sistem informasi dapat dikembangkan karena adanya kebijakan dan perencanaan telebih dahulu. Tanpa adanya perencanaan sistem yang baik, pengembangan sistem tidak akan dapat berjalan sesuai dengan yang diharapkan. Tanpa adanya kebijakan pengembangan sistem oleh manajemen puncak, maka pengembangan sistem tidak akan mendapat dukungan dari manajemen puncak tersebut.

5. Lepas dari berbagai variasi proyek-proyek teknologi informasi yang ada - seperti pembuatan aplikasi, penerapan perangkat lunak, konstruksi infrastruktur jaringan, dan lain sebagainya - metodologi yang dipergunakan secara umum adalah sama. Setidak-tidaknya ada enam buah tahapan yang harus dilalui: perencanaan, analisa, desain, konstruksi, implementasi, dan pasca implementasi. 